Estratégias de manejo do solo em áreas de transição agroecológica
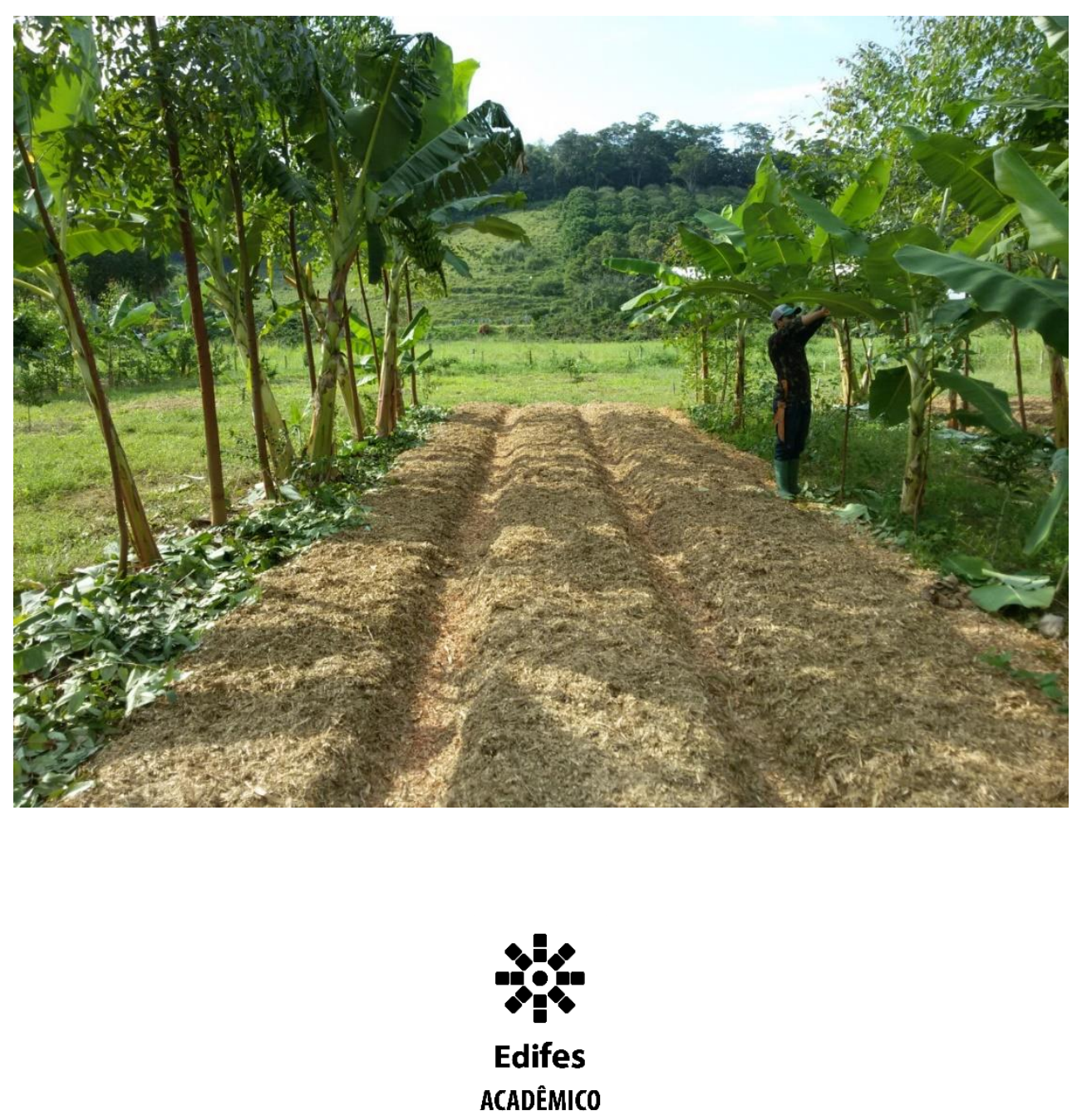
ISBN 978-65-86361-70-4

Novembro/2020

Programa de Pós-Graduação em Agroecologia

Instituto Federal do Espírito Santo - Campus de Alegre

BOLETIM TÉCNICO № 3

Estratégias de manejo do solo em áreas de transição agroecológica

Camilla de Oliveira Souza

Dione Henrique Breda Binoti

Thiago Blunck Rezende Moreira

Otacílio José Passos Rangel

Ifes-Campus de Alegre

Alegre, ES 


\section{* \\ Edifes \\ ACADÊMICO}

Exemplares digitais deste boletim técnico podem ser obtidos em:

Programa de Pós-Graduação em Agroecologia (PPGA)

Instituto Federal do Espírito Santo (Ifes) Campus de Alegre

Rodovia ES 482, km 47, Cx. Postal-47, 29500-000 Distrito de Rive, Alegre-ES

Telefone: (28)

3564-1808

www.ppga.alegre.ifes.edu.br

Reitor: Jadir Jose Pela

Pró-Reitor de Administração e Orçamento: Lezi José Ferreira

Pró-Reitor de Desenvolvimento Institucional: Luciano de Oliveira Toledo

Pró-Reitora de Ensino: Adriana Pionttkovsky Barcellos

Pró-Reitor de Extensão: Renato Tannure Rotta de Almeida

Pró-Reitor de Pesquisa e Pós-Graduação: André Romero da Silva

Coordenador da Edifes: Adonai José Lacruz

\section{Comissão de Editoração}

Otacilio José Passos Rangel, Ana Paula Candido Gabriel Berilli, Aparecida de Fátima Madella de Oliveira, Danielle Inácio Alves, Jeane de Almeida Alves, Jéferson Luiz Ferrari, Maurício Novaes Souza, Monique Moreira Moulin, Pedro Pierro Mendonça

\section{Revisão Textual}

Maurício Novaes Souza

\section{Editoração Eletrônica}

Os autores

\section{Capa}

Lorena Abdalla de Oliveira Prata Guimarães

Estratégias de manejo do solo em áreas de transição agroecológica [recurso eletrônico] / Camilla de Oliveira Souza ... [et.al.]. - Alegre: Instituto Federal de Educação, Ciência e Tecnologia do Espírito Santo, 2020.

$29 \mathrm{f}$. il.

ISBN: 978-65-86361-70-4

Inclui referências.

formato: livro digital (e-book PDF)

veiculação: digital

1. Ecologia agrícola. 2. Agricultura sustentável. 3. Solos - Qualidade. I. Binoti, Dione Henrique Breda. II. Moreira, Thiago Blunk Rezende. III. Rangel, Otacílio José Passos. IV. Título.

@2020 Instituto Federal do Espírito Santo

Todos os direitos reservados.

É permitida a reprodução parcial desta obra, desde que citada a fonte.

O conteúdo dos textos é de inteira responsabilidade dos autores.

DOI: $10.36524 / 9786586361704$ 


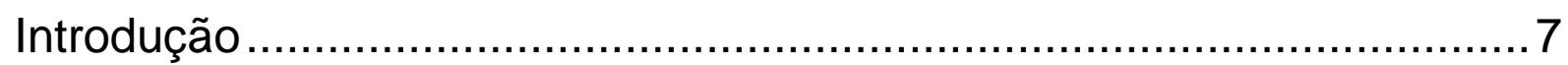

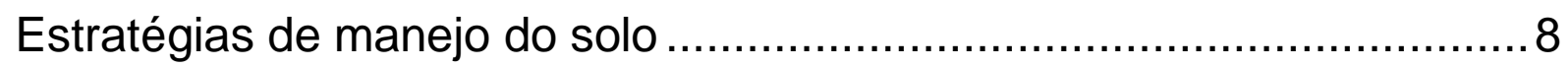

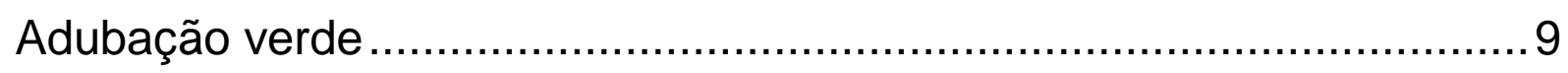

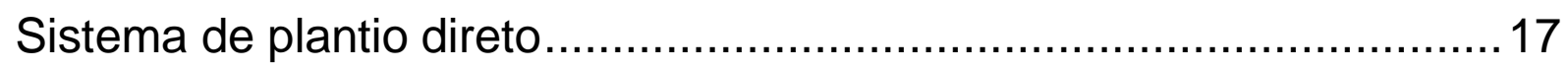

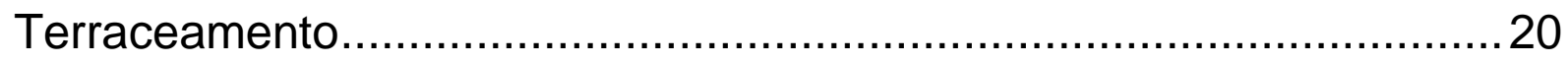

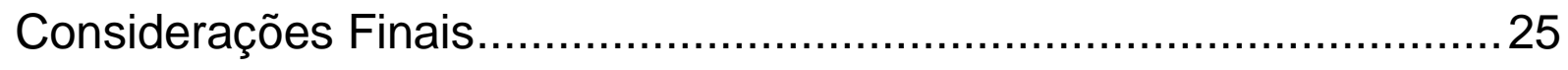

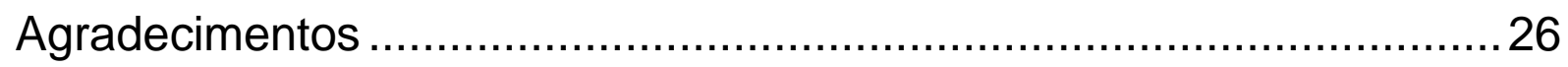

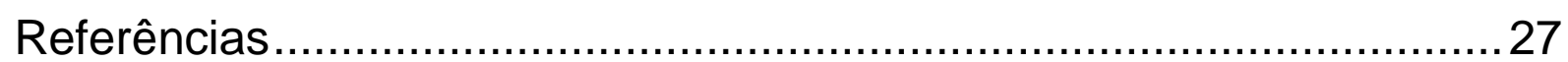




\title{
Estratégias de manejo do solo em áreas de transição agroecológica
}

\author{
${ }^{1}$ Camilla de Oliveira Souza \\ ${ }^{2}$ Dione Henrique Breda Binoti \\ ${ }^{3}$ Thiago Blunck Rezende Moreira \\ ${ }^{4}$ Otacílio José Passos Rangel
}

\begin{abstract}
Resumo - A transição agroecológica é um processo gradual e multilinear, no qual ocorre a conversão de um sistema de produção convencional para um sistema que utiliza práticas conservacionista de manejo do solo. Entre as principais estratégias adotadas em sistemas agroecológicos, destacam-se a adubação verde, o sistema plantio direto e o terraceamento. Essas práticas melhoram os atributos físicos, químicos e biológicos do solo e, por consequência, elevam sua fertilidade. Contudo, o manejo do solo em áreas de transição é um processo complexo, pois varia de acordo com o perfil do produtor, comportamento das espécies e dos recursos disponíveis na propriedade, sendo os benefícios observados a médio e longo prazo. Neste sentido, por meio de revisão de literatura, o presente trabalho teve o objetivo de descrever as principais práticas de manejo do solo adotadas em áreas de transição agroecológica.
\end{abstract}

Termos para indexação: qualidade do solo, práticas conservacionistas, adubação verde, sistema plantio direto, terraceamento.

1Doutoranda pelo Programa de Pós-Graduação em Produção Vegetal da Universidade Federal do Espírito Santo - Alto Universitário, s/n, CEP: 29500-000, Alegre-ES. E-mail: camilladeoveirasouza@hotmail.com

${ }^{2}$ Doutorando pelo Programa de Pós-Graduação em Produção Vegetal da Universidade Federal do Espírito Santo - Alto Universitário, s/n, CEP: 29500-000, Alegre-ES. E-mail: dionebinoti@hotmail.com

${ }_{3}^{3}$ Mestrando pelo Programa de Pós-Graduação em Agroecologia do Instituto Federal do Espírito Santo - Campus de Alegre, Rodovia BR-482, Km 47, distrito de Rive-ES CEP: 29500-000, Alegre-ES. E-mail: tbrmoreira@hotmail.com

${ }^{4}$ Dr. Professor do Instituto Federal do Espírito Santo - Campus de Alegre, Caixa Postal 47, CEP: 29500000, Alegre-ES. E-mail: olprangel@ifes.edu.br 


\title{
Soil management strategies in agroecological transition areas
}

\begin{abstract}
The agroecological transition is a gradual and multilinear process, through which the conversion from a conventional production system to a system that uses conservation soil management practices. The main strategies adopted in agroecological systems are green manure, no-till system and terracing. These practices improve the physical, chemical and biological attributes of the soil and, consequently, increase its fertility. However, soil management in transition areas is a complex process, as it varies with the profile of the farmer, the behavior of species and the resources available on the property, with the benefits being seen in the medium and long term. In this sense, through a literature review, the present study aimed to describe the main soil management practices adopted in areas of agroecological transition.
\end{abstract}

Index terms: soil quality, conservation practices, green manure, no-tillage system, terracing. 
BOLETIM TÉCNICO - № 3

\section{Introdução}

A transição agroecológica é um processo gradual e multilinear de mudança de sistemas de manejo que ocorre em uma área ao longo dos anos. Na agricultura, essa transição acontece por meio da conversão de um sistema de produção convencional para um sistema que utiliza práticas conservacionistas de manejo do solo.

O processo de transição não é simples, pois - entre outros aspectos - varia em função do perfil do produtor, das condições locais e das mudanças climáticas ocorridas ao longo dos anos. Por isso, no começo da transição, é indicado que o produtor participe de um grupo com outros agricultores e assistência técnica especializada, para que todos possam trocar experiências, tirar dúvidas e somar esforços (FEIDEN, 2002).

Por se tratar de um processo que interage com o produtor, a transição agroecológica busca não apenas uma maior racionalização econômica e produtiva, mas também uma mudança nas atitudes e valores dos agricultores em relação ao manejo e conservação dos recursos naturais (CAPORAL e COSTABEBER, 2004). Nesse aspecto, é fundamental que o agricultor esteja motivado a fazer mudanças, com um planejamento para vários anos, pois os resultados só serão observados a médio e longo prazo.

De acordo com Feiden (2002), existem, basicamente, três estratégias para se fazer a conversão do sistema convencional para o agroecológico, sendo elas: conversão radical e imediata de toda a propriedade; conversão radical de parte da propriedade e; conversão lenta e gradual.

$\mathrm{Na}$ conversão radical e imediata de toda a propriedade, a transição de sistemas ocorre de uma única vez num determinado momento. Nessa estratégia, caso a propriedade seja muito dependente de insumos químicos, há uma significativa queda na produtividade das culturas e ataques de pragas e doenças no início do processo, pois o sistema se encontra desequilibrado e muito dependente. Mas, com o passar do tempo, a produtividade volta a crescer à medida que o sistema se equilibra.

$\mathrm{Na}$ conversão radical de parte da propriedade, uma área é mantida no sistema convencional. Nesse caso, a propriedade é dividida em partes e após a consolidação de uma área, a outra inicia o processo de transição até que toda propriedade seja convertida. A perda de produtividade ocorre em etapas e volta a crescer à medida que o sistema se equilibra.

$\mathrm{Na}$ conversão lenta e gradual da propriedade, adota-se práticas conservacionistas aos poucos e ao longo dos anos. Essa estratégia é a mais demorada para se conseguir respostas do sistema, mas permite que o agricultor aprenda as práticas e avance no processo de maneira mais segura, principalmente ao adotar processos mais complexos. 
BOLETIM TÉCNICO - № 3

Os principais passos para se realizar a transição lenta e gradual englobam a racionalização e substituição de insumos químicos; a diversificação e integração de atividades na propriedade; o redesenho da paisagem; a utilização de sistemas complexos de produção e o reordenamento regional (FEIDEN, 2002). Estes passos não precisam seguir uma ordem ou padrão, pois não existem pacotes prontos para a adoção de sistemas agroecológicos. Tudo irá depender do perfil da propriedade e do agricultor. Em alguns casos, quando as condições locais e econômicas são favoráveis, pode-se adotar várias práticas de manejo do solo simultaneamente.

Em razão da variedade e complexidade das estratégias de manejo conservacionista do solo, prosseguem questionamentos a respeito de como o produtor pode iniciar o processo de conversão de sua propriedade. Neste sentido, o presente trabalho teve o objetivo de descrever as principais práticas de manejo do solo adotadas em áreas de transição agroecológica.

\section{Estratégias de manejo do solo}

O solo é um sistema vivo, onde ocorrem interações entre plantas, animais e microrganismos com o meio físico. Essas interações garantem a qualidade do solo, sendo fundamentais para a manutenção da sua sustentabilidade (KARLEN et al., 1997).

A qualidade do solo é definida como a capacidade do mesmo funcionar dentro de um ecossistema natural ou manejado, proporcionando condições físicas, químicas e biológicas necessárias para o bom desenvolvimento de plantas e animais, que resultam no incremento da produtividade agrícola (DORAN e PARKIN, 1994; ARANATI et al., 2009).

Em um sistema de produção agroecológico é preciso adotar uma série de princípios que promovam a sustentabilidade do solo, tais como: manter a vida e a fertilidade do solo, por meio de cobertura vegetal viva ou morta; promover a biodiversidade funcional, por meio da biota do solo e; adaptar atividades agrícolas aos ciclos naturais da região. Entre outras vantagens, essas práticas minimizam as perdas por erosão, evitam mudanças bruscas de temperatura e melhoram as propriedades do solo, além de manter a funcionalidade dos organismos que ali vivem (FEIDEN, 2002).

Outros princípios ecológicos também são observados quando se busca a preservação dos recursos naturais por meio do manejo integrado do solo. Cerreta e Aita (2010), citam que os principais aspectos a serem seguidos são: fazer o uso do solo de acordo com a sua capacidade; preservar as nascentes e cursos d'água; fazer a mínima mobilização do solo; garantir a manutenção dos resíduos culturais sobre a superfície do solo; fazer rotação de 
BOLETIM TÉCNICO - № 3

culturas; diversificar os sistemas de produção e plantio; adotar um sistema de manejo integrado de pragas, doenças e plantas espontâneas; monitorar o uso de máquinas e equipamentos e; fazer o uso mínimo de agrotóxicos.

Todos esses princípios combinados levarão a uma agricultura conservacionista que, se bem manejada, será ambientalmente correta e economicamente viável. Neste sentido, nos próximos tópicos serão descritas algumas práticas de manejo do solo adotadas em áreas de transição agroecológica.

\section{Adubação verde}

A adubação verde é a prática de cultivar plantas que, posteriormente, serão incorporadas ao solo. As principais vantagens desse tipo de adubação estão associadas ao aumento na quantidade de fitomassa no solo, que eleva o teor de carbono e matéria orgânica do solo e, por consequência, a capacidade de troca de cátions - CTC do solo. Isso resulta na maior disponibilidade de nutrientes para as plantas e na redução das perdas destes por lixiviação, além de diminuir os teores de alumínio trocáveis, pela produção de ácidos orgânicos capazes de complexar íons $\mathrm{Al}^{+3}$ presentes na solução do solo (LIU e HUE, 1996; SAGRINO et al., 2009).

Em sistemas de cultivo que adotam a adubação verde, há significativa redução no revolvimento do solo, o que aumenta sua qualidade, antes deteriorada pelo sistema de plantio convencional. Na recuperação de uma área degradada, por exemplo, a adição e balanço de matéria orgânica são fundamentais para melhorar os atributos físicos, químicos e biológicos do solo (CALEGARI, 2006).

Entre as espécies que comumente são empregadas como adubos verdes, destacam-se plantas da família Fabaceae (leguminosas), Poaceae (gramíneas) e Brassicaceae, que desenvolvem uma relação simbiótica com as bactérias dos gêneros Rhizobium e Bradyrhizobium alojadas em suas raízes e estimulam a população de fungos micorrízicos. Tais bactérias captam e metabolização o nitrogênio do solo, enquanto os fungos aumentam a absorção de água e outros nutrientes pelas raízes das plantas (SAGRILO et al., 2009).

As leguminosas são as espécies mais utilizadas como adubo verde. Essa preferência ocorre devido a sua capacidade de simbiose com bactérias fixadoras de nitrogênio, rusticidade, elevada produção de matéria seca e sistema radicular profundo e ramificado, capaz de extrair nutrientes em diferentes profundidades e contribuir para a descompactação do solo (SILVA e MENEZES, 2007). 


\section{BOLETIM TÉCNICO - № 3}

Espécies que possuem sistema radicular profundo e ramificado absorvem nutrientes de camadas mais profundas do solo, movimentando-os gradualmente até a superfície. Isso contribui na reposição da fertilidade do solo e diminui sua dependência por insumos químicos de alta solubilidade (CARVALHO et al., 2004).

Em áreas de transição agroecológica, antes do plantio do adubo verde, deve-se observar alguns fatores para se definir as estratégias de manejo do solo. Inicialmente, deve-se fazer o diagnóstico da área a fim de avaliar os aspectos físicos, químicos e biológicos do solo e observar a ocorrência de espécies espontâneas, pragas e doenças nas áreas de interesse agrícola e entorno.

Deve-se estabelecer o objetivo de plantio de acordo com o interesse econômico, os recursos financeiros, a operacionalidade e a infraestrutura que o produtor tem disponível. $O$ nível de conhecimento do produtor e a disponibilidade de assistência técnica especializada é outro fator importante para se determinar as estratégias de manejo do solo.

Avaliar o histórico de uso do solo e o nível de preocupação ambiental do produtor é fundamental para entender sua relação com a propriedade e saber até que ponto ele está disposto a modificar e investir no novo sistema de plantio.

Por fim, devem-se conhecer as condições edafoclimáticas da região e o comportamento das plantas de interesse comercial, para determinar quais espécies de adubos verdes se adequarão às condições de plantio. De acordo com Espíndola et al. (2005), cada espécie vegetal possui necessidades nutricionais específicas e, para não haver competição entre as culturas, deve-se escolher adubos verdes a partir das caraterísticas das plantas de interesse comercial e das condições edafoclimáticas da propriedade.

Algumas plantas apresentam problemas quando cultivadas próximas ou em sucessão, como mostra a tabela 1. Durante a escolha de espécies de leguminosas para adubação verde, por exemplo, deve-se considerar alguns aspectos, que são descritos na tabela 2. 
BOLETIM TÉCNICO - № 3

Tabela 1. Exemplos de plantas que não devem ser cultivadas próximas ou em sucessão.

\begin{tabular}{|c|c|}
\hline Cultura principal & Culturas prejudiciais \\
\hline Abóbora & Batata, legumes tuberosos e rabanete \\
\hline Alface & Espinafre, girassol e salsa \\
\hline Batata & $\begin{array}{c}\text { Abóbora, aipo, berinjela, beterraba, cebola, couve, ervilha, framboesa, } \\
\text { girassol, maçã, milho, pepino e tomate }\end{array}$ \\
\hline Berinjela & Batata e cebola \\
\hline Beterraba & $\begin{array}{l}\text { Alho-poró, batata, cenoura, espargo, feijão, feijão-trepador, milho, } \\
\text { tomate }\end{array}$ \\
\hline Brócolis & Morango \\
\hline Cebola & Batata, couve, ervilha, feijão e repolho \\
\hline Milho & Aipo, alecrim, alface, batata, beterraba e hortelã \\
\hline Morango & Repolho \\
\hline Salsa & Alface, ervilha, feijão e repolho \\
\hline Tomate & Batata, beterraba, couve, erva-doce, ervilha, feijão e pepino \\
\hline
\end{tabular}

Fonte: Adaptado de Moreira (2013).

Tabela 2. Comportamento de leguminosas herbáceas utilizadas como adubo verde.

\begin{tabular}{|c|c|c|c|c|}
\hline $\begin{array}{c}\text { Nome } \\
\text { comum }\end{array}$ & Nome científico & Ciclo & $\begin{array}{c}\text { Hábito de } \\
\text { crescimento }\end{array}$ & Ambiente de cultivo \\
\hline Feijão-bravo & $\begin{array}{l}\text { Canavalia } \\
\text { brasiliensis }\end{array}$ & Anual & Volúvel & $\begin{array}{c}\text { Adaptada a condições de } \\
\text { seca }\end{array}$ \\
\hline $\begin{array}{l}\text { Feijão-de- } \\
\text { porco }\end{array}$ & $\begin{array}{l}\text { Canavalia } \\
\text { ensiformis }\end{array}$ & Anual & Ereto & $\begin{array}{c}\text { Adaptada a condições de } \\
\text { sombreamento e de baixa } \\
\text { fertilidade do solo }\end{array}$ \\
\hline Crotalária & Crotalaria juncea & Anual & Ereto & $\begin{array}{l}\text { Adaptada a condições de } \\
\text { baixa fertilidade do solo }\end{array}$ \\
\hline Mucuna-preta & $\begin{array}{l}\text { Stizolobium } \\
\text { aterrimum }\end{array}$ & Anual & Volúvel & $\begin{array}{l}\text { Adaptada a condições de } \\
\text { baixa fertilidade do solo }\end{array}$ \\
\hline Siratro & $\begin{array}{l}\text { Macroptilium } \\
\text { atropurpureum }\end{array}$ & Perene & Volúvel & $\begin{array}{l}\text { Adaptada a condições de } \\
\text { baixa fertilidade do solo }\end{array}$ \\
\hline $\begin{array}{l}\text { Cudzu } \\
\text { tropical }\end{array}$ & $\begin{array}{c}\text { Pueraria } \\
\text { phaseoloides }\end{array}$ & Perene & Volúvel & $\begin{array}{l}\text { Adaptada a baixadas } \\
\text { umidades, sombreamento } \\
\text { e baixa fertilidade do solo }\end{array}$ \\
\hline Centrosema & $\begin{array}{l}\text { Centrosema } \\
\text { pubescens }\end{array}$ & Perene & Volúvel & $\begin{array}{c}\text { Adaptada a baixadas } \\
\text { umidades }\end{array}$ \\
\hline $\begin{array}{l}\text { Amendoim- } \\
\text { forrageiro }\end{array}$ & Arachis pintoi & Perene & Rastejante & $\begin{array}{l}\text { Adaptada a condições de } \\
\text { baixa fertilidade do solo }\end{array}$ \\
\hline
\end{tabular}

Leguminosas de hábito de crescimento volúvel podem atuar como trepadeiras, havendo algumas restrições quando consorciadas a outras culturas. Espécies anuais completam seu ciclo vegetativo em poucos meses, cobrindo o solo com restos vegetais durante a queda de suas folhas. As espécies perenes, por não perder folhas durante a floração, formam uma cobertura viva e permanente no solo (ESPÍNDOLA et al., 2005).

Espécies de outras famílias também demostram grande potencial de utilização como adubo verde. Gramíneas como o milho (Zea mays), centeio (Cecale cereale), aveia preta (Avena 
BOLETIM TÉCNICO - № 3

strigosa), azevém (Lolium multiflorum), milheto (Pennisetum glaucum), sorgo (Sorghum bicolor) e capim sudão (Sorghum sudanense), possuem uma grande quantidade de raízes, que além de enriquecer, agregam partículas e aumentam a porosidade do solo (MOREIRA, 2017a).

O girassol (Helianthus annuus) recicla os nutrientes em profundidade e deixa uma grande quantidade de massa verde sobre o solo, enquanto que o nabo forrageiro - principal representante da família Brassicaceae - contribui na descompactação do solo e na reciclagem de nitrogênio e fósforo das plantas cultivadas (MOREIRA, 2017a).

Dentro das várias possibilidades de manejo do solo, o ideal é fazer o plantio com o maior número possível de espécies. Dessa forma, é possível criar um sistema complexo, que atenda às necessidades da cultura de interesse, como mostram as figuras 1 e 2 .

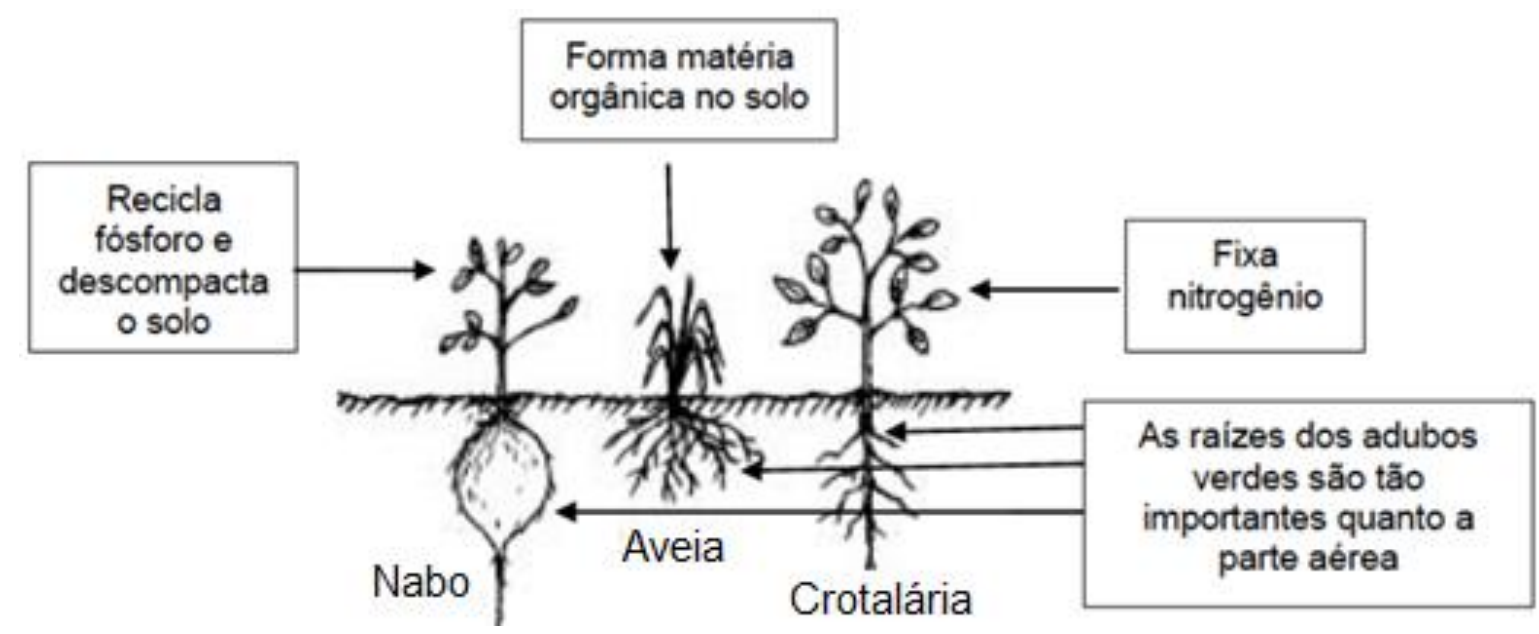

Figura 1. Benefícios do plantio em consorcio com espécies de adubo verde.

Fonte: Moreira (2017a). 


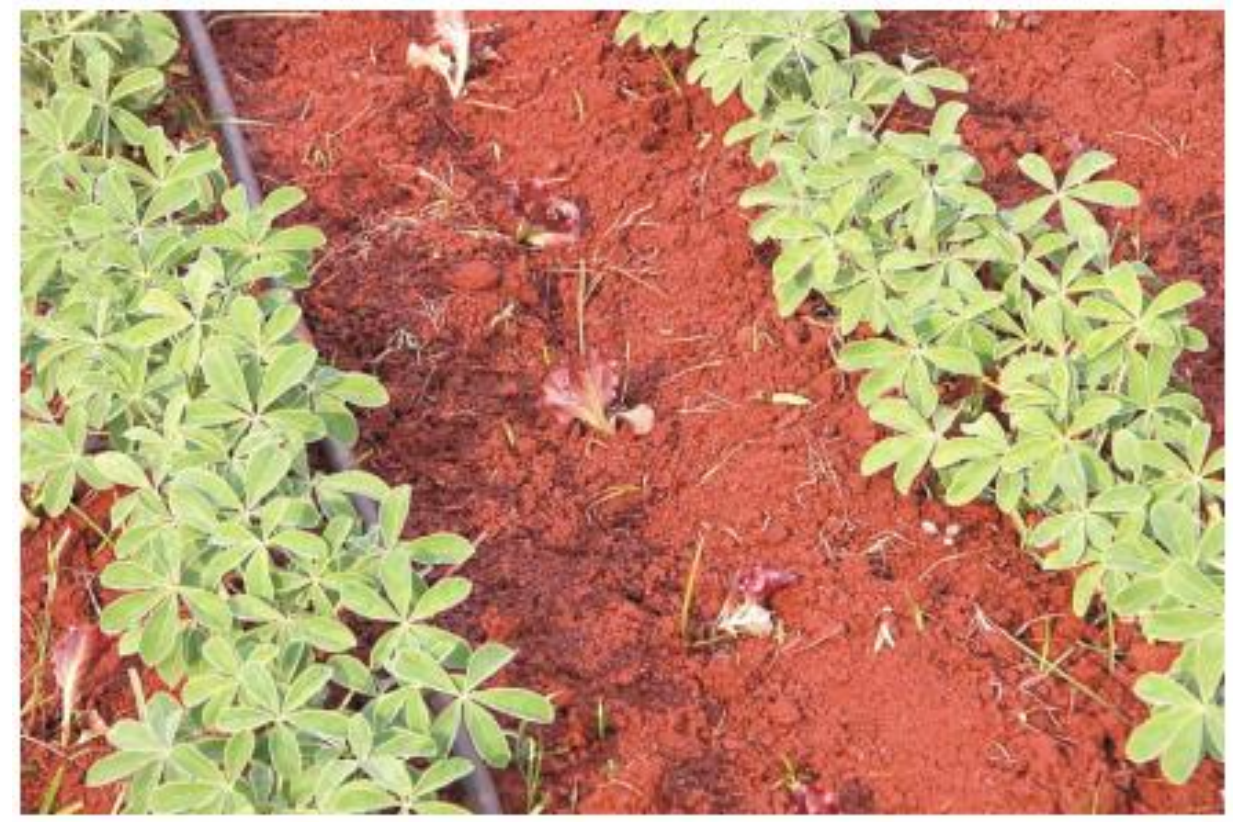

Figura 2. Consórcio de alface com tremoço (nesse sistema, constatou-se que $10 \%$ do nitrogênio contido na alface vieram da fixação biológica do tremoço).

Fonte: Wutke et al. (2007).

Após escolher as espécies de adubos verdes que melhor se enquadram na realidade do produtor, é preciso fazer um planejamento agrícola de todas as atividades que serão realizadas, para que o produtor atinja seus objetivos de plantio. O planejamento é fundamental para o produtor visualizar as mudanças que ocorrerão no ambiente ao longo do tempo, sendo também uma ferramenta de tomada de decisão caso seja necessário adaptar, mudar ou inserir novas práticas de manejo do solo.

De acordo com sua utilização, a adubação verde pode ser classificada pela época do ano durante o plantio (primavera-verão ou outono-inverno) e pelo tipo de cultivo (solteiro ou consorciado), como detalhado nas tabelas 3 e 4. 
Tabela 3. Principais características das modalidades de adubação verde em cultivo solteiro.

\begin{tabular}{|c|c|c|}
\hline & \multicolumn{2}{|c|}{ Modalidade } \\
\hline & $\begin{array}{l}\text { Adubação verde de primavera- } \\
\text { verão em cultivo solteiro }\end{array}$ & $\begin{array}{l}\text { Adubação verde de outono- } \\
\text { inverno em cultivo solteiro }\end{array}$ \\
\hline $\begin{array}{l}\text { Período de } \\
\text { plantio }\end{array}$ & Outubro a janeiro & Fevereiro a abril \\
\hline $\begin{array}{l}\text { Condições } \\
\text { climáticas }\end{array}$ & $\begin{array}{l}\text { Ocorrência de chuvas associadas a } \\
\text { altas temperaturas }\end{array}$ & $\begin{array}{l}\text { Poucas chuvas e temperaturas } \\
\text { mais baixas }\end{array}$ \\
\hline Vantagens & $\begin{array}{l}\text { Produção de grandes quantidades } \\
\text { de fitomassa, aporte de nitrogênio e } \\
\text { renda extra ao produtor }\end{array}$ & $\begin{array}{l}\text { Protege áreas que geralmente } \\
\text { não são cultivadas nessa época } \\
\text { do ano, diminui a população de } \\
\text { plantas espontâneas, podendo } \\
\text { ser fonte de renda extra ao } \\
\text { produtor }\end{array}$ \\
\hline Desvantagens & $\begin{array}{l}\text { Ocupação de áreas agrícolas } \\
\text { durante o período mais propício } \\
\text { para o cultivo de plantas de } \\
\text { interesse econômico, o que pode } \\
\text { ser contornado com rodízio de áreas } \\
\text { para adubação verde }\end{array}$ & $\begin{array}{l}\text { Reduzida produção de fitomassa, } \\
\text { devida às condições climáticas } \\
\text { em regiões mais frias }\end{array}$ \\
\hline $\begin{array}{l}\text { Espécies mais } \\
\text { utilizadas }\end{array}$ & $\begin{array}{l}\text { Espécies de crotalárias } \\
\text { Espécies de mucunas } \\
\text { Feijão-bravo-do-ceará } \\
\text { Feijão-de-porco } \\
\text { Guandu } \\
\text { Soja } \\
\text { Milho } \\
\text { Milheto } \\
\text { Sorgo } \\
\text { Girassol }\end{array}$ & $\begin{array}{l}\text { Chícharo } \\
\text { Espécies de Tremoço } \\
\text { Ervilha } \\
\text { Grão-de-bico } \\
\text { Ervilhaca } \\
\text { Aveia branca } \\
\text { Aveia preta } \\
\text { Centeio } \\
\text { Trigo } \\
\text { Nabo forrageiro }\end{array}$ \\
\hline
\end{tabular}

Fonte: Adaptado de Espíndola et al. (1997) e Wutke et al. (2007).

O preparo do solo é um fator determinante no sistema de produção. Em áreas de transição ecológica, geralmente os solos se encontram esgotados pelo uso intensivo da terra, sendo recomendado fazer a análise do solo, a fim de detectar a necessidade de correção, adubação ou descompactação antes da semeadura.

No início, também é preciso fazer o controle da população de plantas espontâneas. De acordo com Wutke et al. (2007), geralmente esse controle é estendido até os 45-50 dias do ciclo dos adubos verdes e pode ser realizado nas entrelinhas por meio de capinas manuais (enxadas) ou mecânicas (cultivador ou roçadeira). 
BOLETIM TÉCNICO - № 3

Tabela 4. Principais características das modalidades de adubação verde consorciadas.

\begin{tabular}{|c|c|c|}
\hline & \multicolumn{2}{|c|}{ Modalidade } \\
\hline & $\begin{array}{c}\text { Adubação verde consorciada com } \\
\text { culturas anuais }\end{array}$ & $\begin{array}{c}\text { Adubação verde consorciada } \\
\text { com culturas perenes }\end{array}$ \\
\hline Manejo & $\begin{array}{l}\text { O adubo verde é semeado nas } \\
\text { entrelinhas da cultura de interesse } \\
\text { econômico }\end{array}$ & $\begin{array}{l}\text { O adubo verde é cultivado entre as } \\
\text { linhas de frutíferas ou de outras } \\
\text { plantas perenes }\end{array}$ \\
\hline Vantagens & Maior eficiência no uso da terra & $\begin{array}{l}\text { Formação de uma cobertura viva } \\
\text { permanente, sem que haja } \\
\text { necessidade de novos plantios a } \\
\text { cada ano }\end{array}$ \\
\hline Cuidados & $\begin{array}{l}\text { O consórcio entre leguminosas e } \\
\text { culturas anuais deve ser evitado em } \\
\text { períodos de reduzida disponibilidade } \\
\text { de água, pois pode ocasionar quedas } \\
\text { de produção }\end{array}$ & $\begin{array}{l}\text { As leguminosas com hábito de } \\
\text { crescimento volúvel devem ser } \\
\text { recomendadas com cautela, } \\
\text { procedendo-se o coroamento das } \\
\text { culturas perenes }\end{array}$ \\
\hline $\begin{array}{l}\text { Consórcio } \\
\text { de espécies }\end{array}$ & $\begin{array}{l}\text { Milho + feijão-de-porco } \\
\text { Batata-doce + crotalária } \\
\text { Abóbora + guandu } \\
\text { Cana + crotalária } \\
\text { Berinjela + caupi }\end{array}$ & $\begin{array}{l}\text { Banana + cudzu tropical } \\
\text { Café + guandu } \\
\text { Maracujá + amendoim forrageiro }\end{array}$ \\
\hline
\end{tabular}

A época de semeadura é outro fator importante. Deve-se observar as condições climáticas mais favoráveis ao desenvolvimento das plantas e suas adaptações ao cultivo no período de primavera-verão ou outono-inverno, sendo as sementes submetidas, quando necessário, à procedimentos de quebra de dormência e inoculação com bactérias específicas, como mostra a figura 3.

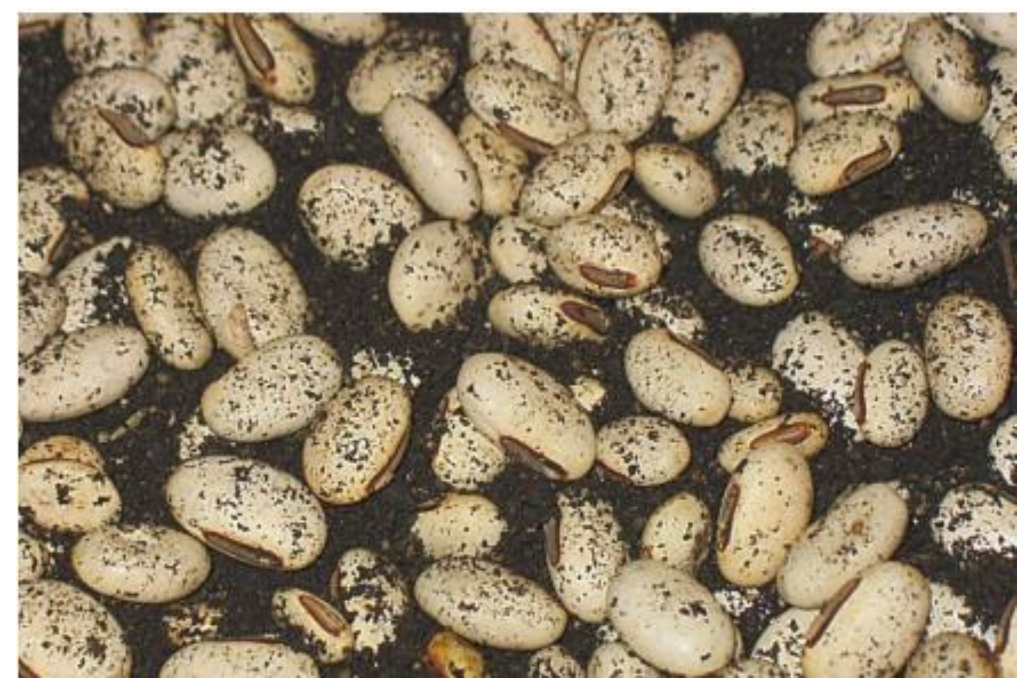

Figura 3. Sementes de feijão-de-porco inoculadas (inoculante: mistura de pó de turfas e bactérias específicas para cada planta).

Fonte: Wutke et al. (2007). 


\section{BOLETIM TÉCNICO - № 3}

De modo geral, a época do ano mais favorável para a semeadura é na primavera-verão, podendo se estender até junho em algumas regiões onde o clima permanece chuvoso, com altas temperaturas e amplo fotoperíodo. Essas condições são ideais para o desenvolvimento vegetativo e reprodutivo da maioria das espécies vegetais (WUTKE et al., 2007).

A época de semeadura das plantas de cobertura, sobretudo daquelas desenvolvidas no verão-outono, varia em função do seu hábito de crescimento. Para as espécies eretas, como é o caso do feijão guandu e das crotalárias, a semeadura deve ser feita tardiamente (setembro-outubro), o que resulta em sua redução de altura e facilidade na colheita de vagens e grãos (WUTKE et al., 2007).

A semeadura dos adubos verdes pode ser realizada em linhas, a lanço ou em covas, sendo a semeadura em linhas a forma mais utilizada. O espaçamento adotado varia de acordo com as espécies, o objetivo de plantio e a época do ano. Em leguminosas, por exemplo, o espaçamento médio é de $50 \mathrm{~cm}$ em qualquer época do ano e de $90 \mathrm{~cm}$ quando o objetivo é a produção de sementes. Já a profundidade de semeadura varia de acordo com a forma e o tamanho das sementes, devendo ser de 2,5 a 3 vezes maior do que seu diâmetro (WUTKE et al., 2007).

A quantidade e o tempo de permanência da fitomassa produzida pelo adubo verde no solo irá depender do plano de manejo da unidade de produção. Em geral, a poda ou a colheita dos adubos verdes devem ser realizadas durante a floração ou formação das primeiras vagens. Nas espécies perenes, a altura de poda deve permitir sua rebrota natural (MOREIRA, 2017b).

No caso das leguminosas, o corte deve ser realizado quando a planta atinge $80 \%$ de floração. Neste momento, o nitrogênio se encontra mais disponível, devendo a fitomassa ser acamada na superfície do solo ou incorporada numa profundidade de 8-10 cm (MOREIRA, 2017b).

A colheita dos adubos verdes pode ser feita de forma manual ou mecânica, com o uso de foice, roçadeira costal, roçadeira tratorizada ou qualquer outro equipamento disponível na propriedade, como mostra a figura 4. Entretanto, o uso da grade aradora deve ser evitado, principalmente em sistemas que adotam o plantio direto, por agravar a compactação da camada superficial e reduzir o tamanho dos agregados do solo (WUTKE et al., 2007). 

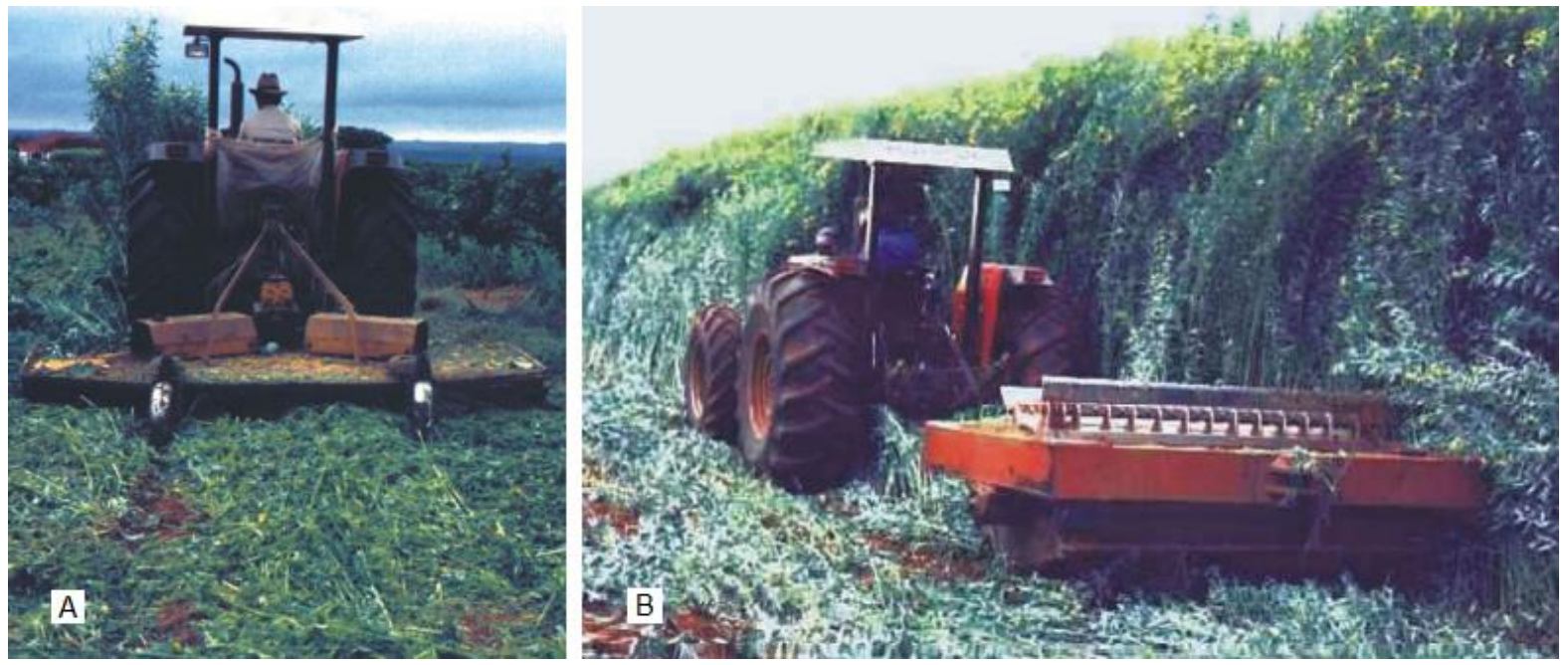

Figura 4. Manejo do solo com (A) roçadeira e (B) rolo-faca.

Fonte: Wutke et al. (2007).

\section{Sistema plantio direto}

A cada dia a produção agrícola sofre mais com as perdas de solo em áreas cultivadas. Essas perdas são ocasionadas, principalmente, pelas intensas chuvas que arrastam agregados e nutrientes em solos desprotegidos, que muitas vezes se encontram em um avançado estágio de degradação (SALOMÃO et al., 2019).

Sistemas de cultivo convencional prejudicam ainda mais esta situação, diminuindo a qualidade do solo e, consequentemente, a produção agrícola (ADAMS, 2016). Nesse contexto, o sistema plantio direto - SPD torna-se uma alternativa de manejo sustentável, capaz de melhorar os atributos químicos, físicos e biológicos do solo, contribuindo também para o aumento da fertilidade ao longo dos anos.

As principais técnicas empregadas no SPD são a ausência ou mínimo revolvimento do solo, a cobertura do solo com palhada e a rotação de culturas. De acordo com Adams (2016), esse tipo de sistema incrementa a cobertura do solo de forma contínua, por meio de palhadas das culturas advindas do processo de rotação de culturas, que são deixadas sobre o solo para proteger e restaurar sua fertilidade, como mostra a figura 5. 
BOLETIM TÉCNICO - № 3

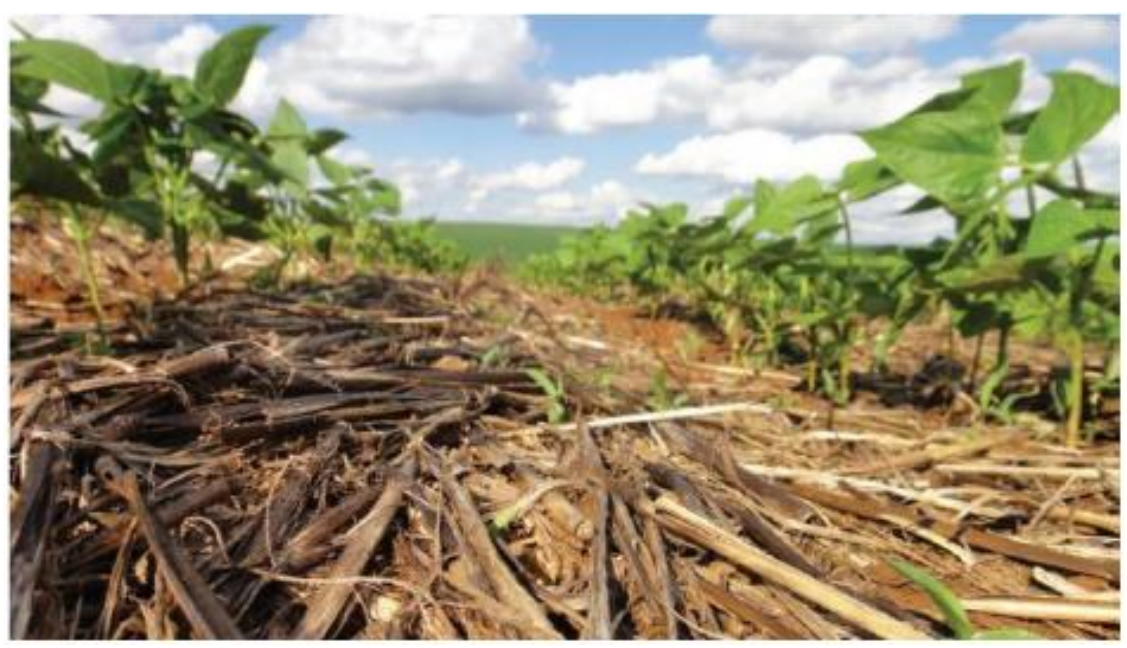

Figura 5. Cobertura vegetal morta proveniente do manejo de rotação de culturas. Fonte: Alvarenga et al. (2001).

A rotação de culturas aumenta o teor de carbono orgânico no solo e reduz as perdas de nutrientes por lixiviação, por haver uma grande decomposição de biomassa agrícola na área de plantio. Entre outras vantagens, essa prática aumenta a ciclagem de nutrientes e faz a manutenção de matéria orgânica no solo (GONÇALVES et al., 2007).

Os restos culturais sobrepostos ao solo também auxiliam na diminuição dos impactos gerados pelo efeito splash da chuva, que podem iniciar ou agravar o processo de erosão em solos desprotegidos (CORRÊA e CRUZ, 1987).

Em áreas de transição ecológica, a cobertura com palhada deve ser mantida independe do sistema e das espécies utilizadas, sendo uma prática simples, que consiste basicamente em deixar os restos vegetais em toda área de plantio. Nesse sentido, quanto maior o volume de biomassa deixada sobre o solo, maior a proteção e manutenção da matéria orgânica, que contribui para o aumento da qualidade do solo.

A rotação e sucessão de culturas são práticas essenciais ao SPD, sendo o plano de manejo desenvolvido, principalmente, em função do objetivo do produtor, da tecnologia disponível, das características edafoclimáticas da região e das espécies de interesse comercial (FIORIN, 2007; ADAMS, 2016).

Em áreas de transição agroecológica, antes da implantação do SPD, deve-se fazer o diagnóstico completo da área e observar a necessidade de correção, adubação e controle de espécies espontâneas, pragas e doenças, sendo este o último momento para fazer o revolvimento nas camadas mais profundas do solo. 
BOLETIM TÉCNICO - № 3

Cada planta possui necessidades nutricionais específicas, sendo importante fazer a escolha das espécies de interesse comercial, de consórcio ou de sucessão de forma que não haja competição, como exemplificado anteriormente na tabela 1.

Espécies de leguminosas e gramíneas são as que mais se destacam no SPD. Na rotação ou sucessão de culturas, as leguminosas podem ajudar na fixação de nitrogênio no solo, enquanto que as gramíneas, devido sua alta relação $\mathrm{C} / \mathrm{N}$, contribuem para a decomposição gradativa da matéria orgânica e agregação das partículas do solo, além de reciclar nutrientes, por meio da fitomassa presente na cobertura do solo (ESPÍNDOLA et al., 1997; FIORIN, 2007).

Ao avaliar o aporte de biomassa e a taxa de liberação de nutrientes no SPD, Teixeira et al. (2009) observaram que em consórcio com crotalária (Crotalaria juncea), o milheto (Pennisetum glaucum) obteve alta produtividade em matéria seca e maior taxa de liberação de macronutrientes na palhada, que ajudou na recuperação de solos degradados.

Contudo, em grande parte das lavouras brasileiras, o SPD não é manejado corretamente. Em áreas de transição agroecológica, a falta de atenção nesse processo pode causar a compactação do solo e prejudicar o desenvolvimento de raízes e os fluxos da água no solo, sendo a diversificação de culturas uma premissa técnica obrigatória para elevar a produção anual de material orgânico neste sistema.

Segundo Denardin et al. (2012), são necessárias cerca de 8 a 12 t ha $^{-1}$ de massa seca de palha e raízes para reciclar a matéria orgânica e manter ativa a biologia do solo. Esse montante só é obtido por meio do cultivo anual de duas ou mais culturas em rotação, consorciação ou sucessão, como exemplificado na tabela 5. 
BOLETIM TÉCNICO - № 3

Tabela 5. Modelos de produção conduzidos sob sistema plantio direto mediante o processo colher-semear, explicitando o ciclo das espécies componentes ao longo dos anos, na região de clima tropical do Brasil. Espécies utilizadas: braquiária (Brachiaria spp); milheto (Pennisetum glaucum L.) R. Br.); milho (Zea mays L.); e soja (Glycine max L. Merrill).

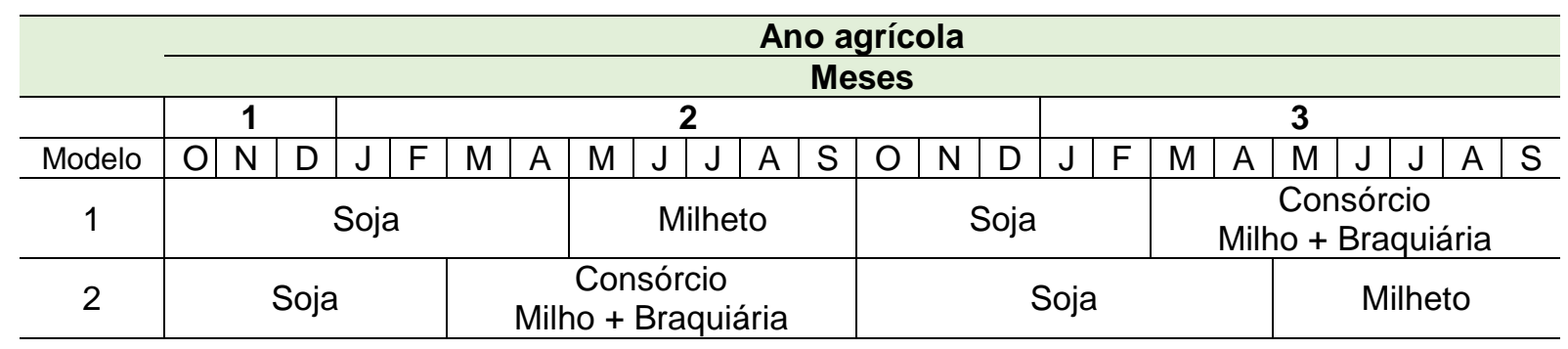

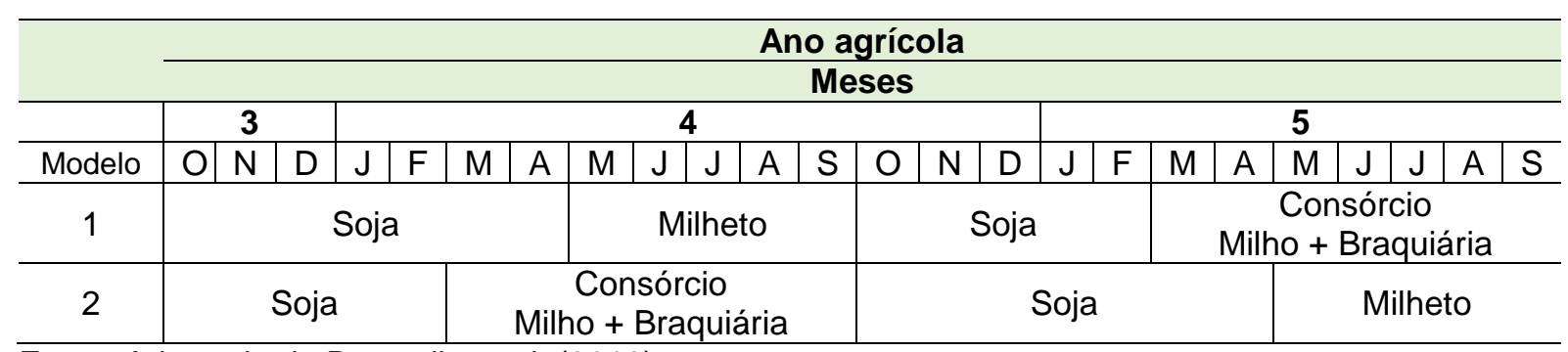

Fonte: Adaptado de Denardin et al. (2012).

\section{Terraceamento}

Mesmo com a utilização da adubação verde e do SPD, as intensas precipitações podem causar perdas significativas de solo e matéria orgânica em áreas íngremes (MACHADO e WADT, 2016). Para controlar os efeitos da erosão hídrica no solo é indicado a associação de diferentes práticas, por exemplo, o manejo do SPD com a adubação verde e o terraceamento.

O terraceamento é uma das práticas mecânicas de conservação do solo mais difundidas na agricultura e tem a finalidade de fazer o controle da erosão hídrica por meio da construção de terraços (BERTOL e COGO, 1996).

O terraço é formado pela combinação de um canal (valeta), que pode ser largo, estreito, profundo ou raso, com um camalhão (monte de terra ou dique), construídos com intervalos dimensionados no sentido transversal a declividade do terreno, como mostra a figura 6 (BERTOL e COGO, 1996).

Os terraços se iniciam na parte superior do terreno e tem a função de interceptar o escoamento superficial da água pluvial, facilitando sua infiltração ou escoamento lento no solo. Quando bem planejados e construídos, os terraços diminuem o volume e a velocidade de vazão da água e minimizam o poder erosivo das enxurradas, evitando a formação de sulcos e voçorocas nas áreas íngremes de plantio (BERTONI e LOMBARDI NETO, 1990). 


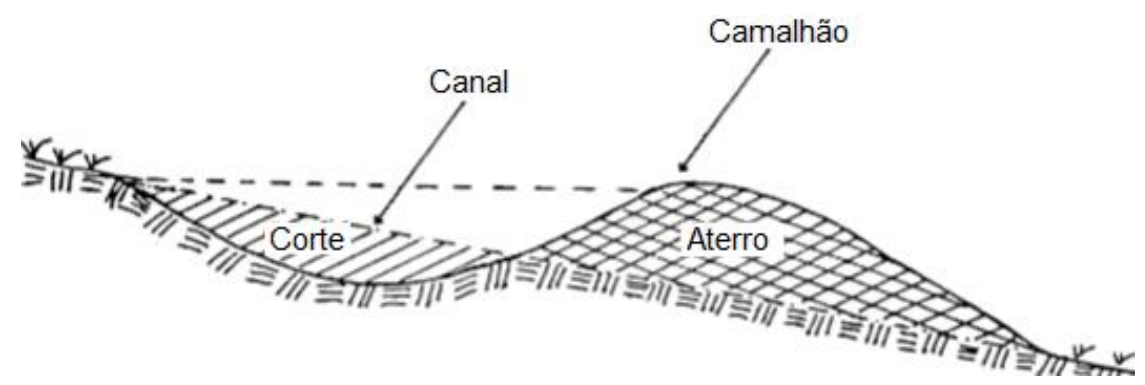

Figura 6. Partes componentes do terraço.

Fonte: Adaptado de Bertol e Cogo (1996).

O tipo do terraço varia de acordo com o objetivo do manejo, topografia e tecnologia disponível na propriedade, podendo ser classificado quanto a sua função, largura da base, processo de construção e forma do perfil do terreno (WADT, 2003).

Basicamente, os terraços exercem duas funções: de retenção ou drenagem. O terraço em nível promove a retenção (infiltração) do excesso de águas pluviais, sendo construído com um canal em nível e extremidades bloqueadas, como mostra a figura 7. O terraço em desnível (com gradiente de drenagem, declive ou de escoamento), drena o excesso de água para fora da área a ser protegida (PRUSKY, 2009).

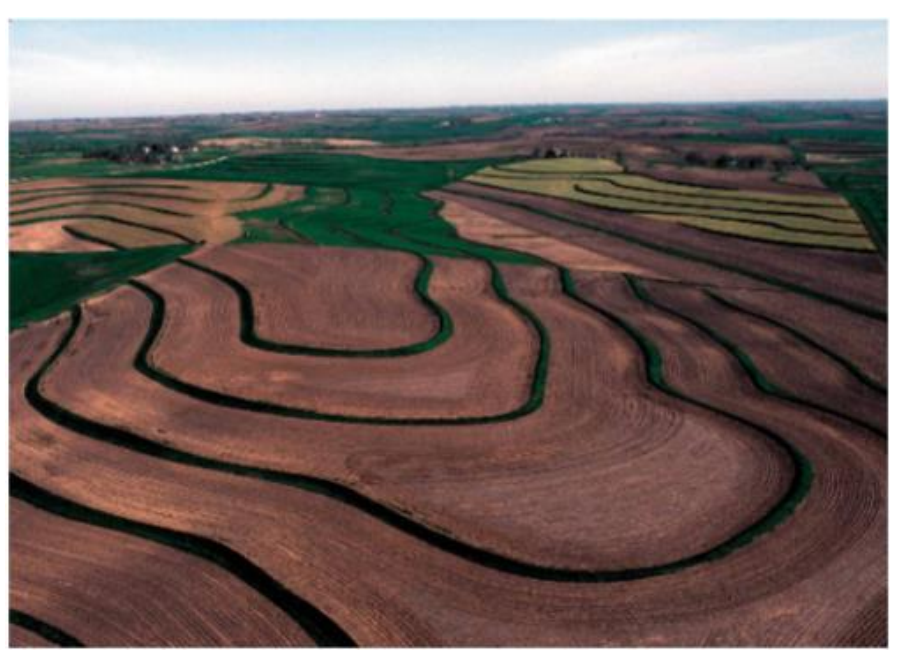

Figura 7. Área com terraço em nível e suas faixas de proteção.

Fonte: Bertol e Cogo (1996).

Os terraços podem apresentar três larguras de base: larga, média ou estreita, como ilustra a Figura 8. 


\section{BOLETIM TÉCNICO - № 3}

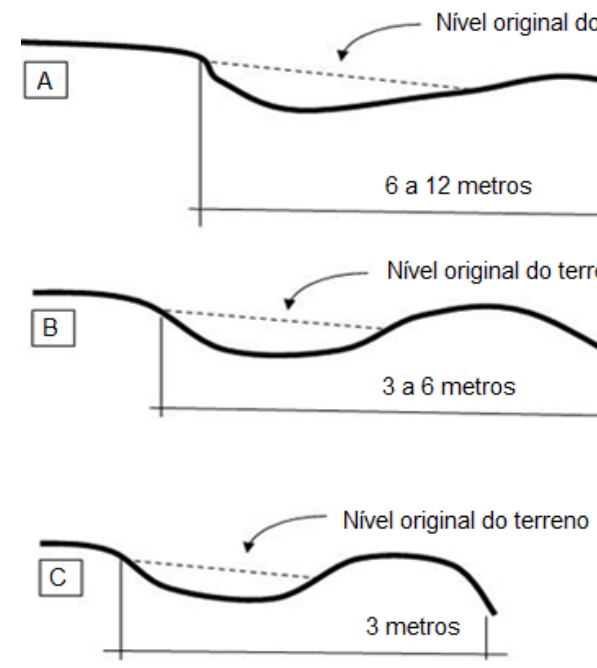

Figura 8. Classificação do terraço quanto a largura de base (A) larga, (B) média e (C) estreita. Fonte: Machado (2016).

O terraço de base larga é indicado para áreas com declividades de 6 a $8 \%$ e utiliza uma faixa de 6 a 12 metros para sua construção, o que possibilita a utilização de implementos agrícolas. O terraço de base média é adequado para declividades de 10 a $12 \%$ e utiliza uma faixa de 3 a 6 metros para sua construção e também possibilita a utilização de implementos agrícolas. Já o terraço de base estreita é utilizado em áreas com declividades superiores a $15 \%$ e possui uma faixa de até 3 metros, o que impossibilita a utilização de implementos agrícolas, sendo o mais indicado para propriedades pequenas ou muito íngremes (PRUSKY, 2009).

Quanto ao processo de construção, existem dois tipos: a) o terraço tipo Nichol's, que movimenta o solo exclusivamente de cima para baixo (Figura 9); e b) o terraço tipo Mangum, que movimenta o solo em ambas as direções (Figura 10), tendo maior capacidade de retenção de água (ZONTA et al., 2012).

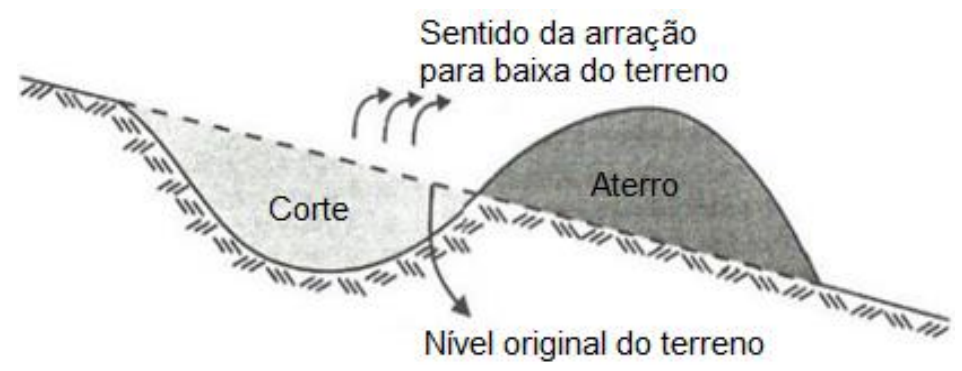

Figura 9. Processo de construção do terraço tipo Nichol's.

Fonte: Adaptado de Prusky (2009). 
BOLETIM TÉCNICO - № 3

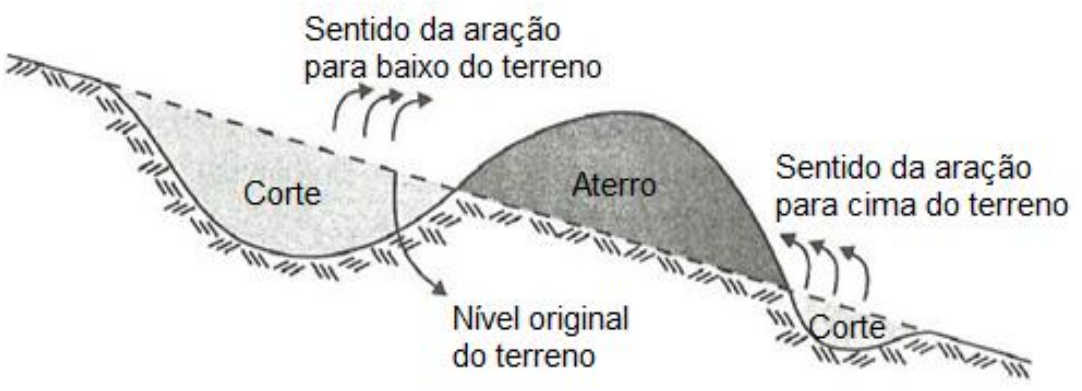

Figura 10. Processo de construção do terraço tipo Mangum.

Fonte: Adaptado de Prusky (2009).

Existem cinco formas de perfil do terraço, sendo eles do tipo: comum, patamar, embutido, murundum e banqueta individual, que são ilustrados na figura 11.
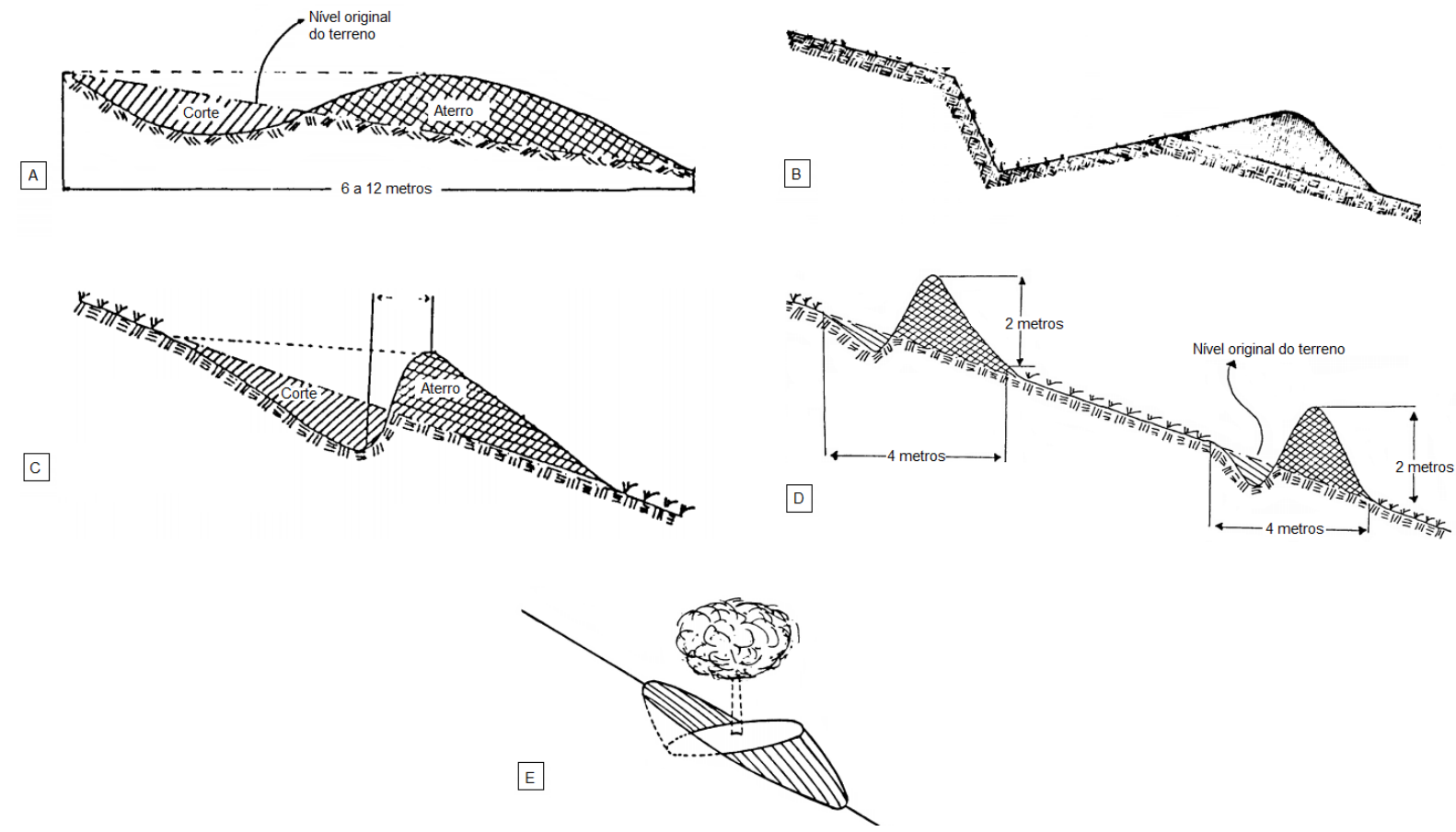

Figura 11. Formas de perfil do terreno: $(A)$ comum, $(B)$ patamar, $(C)$ embutido, $(D)$ murundum e (E) banqueta Individual.

Fonte: Adaptado de Bertol e Cogo (1996).

O terraço do tipo comum é utilizado em terrenos com declividade inferior a $18 \%$. O do tipo patamar abrange uma plataforma onde é feito o cultivo e um talude com cobertura vegetativa, que evita a erosão e facilita o cultivo, devendo ser empregado em terrenos com declividade superior a $18 \%$ (PRUSKY, 2009).

O terraço do tipo embutido é construído verticalmente ao fundo do canal e da crista do talude. Já o terraço do tipo murundum é formado por um camalhão mais alto, sendo indicado 
BOLETIM TÉCNICO - № 3

para locais que necessitem reter um grande volume de água; enquanto o terraço do tipo banqueta individual, possui uma plataforma individual para cada planta, sendo recomendado para declividades superiores a $18 \%$ ou culturas permanentes (PRUSKY, 2009).

No dimensionamento de um sistema de terraceamento, deve-se considerar o objetivo do sistema (infiltração ou escoamento), as condições de declividade e permeabilidade do solo, o manejo da área, as características das plantas e dos restos culturais e a tecnologia disponível na propriedade.

Várias são as equações para determinar o melhor espaçamento vertical e horizontal do terraço, como as propostas por Oliveira et al. (1992) e Lombardi Neto et al. (1994), os quais desenvolveram tabelas de espaçamento entre terraços em função de um efetivo controle de erosão.

Dessa forma, a decisão de utilizar terraço em áreas de transição agroecológica deve ser tomada logo no início do processo, pois influencia diretamente no manejo que o agricultor pretende desenvolver na área, sendo este, talvez, o último momento indicado para se fazer o revolvimento das camadas mais profundas do solo. Além disso, deve-se considerar as principais vantagens e desvantagens de cada tipo de terraço para facilitar a tomada de decisão durante o manejo do solo, conforme mostra a Tabela 6.

Tabela 6. Principais características dos terraços tipo nível e em desnível.

\begin{tabular}{ccc}
\hline Tipo de terraço & Vantagens & Desvantagens \\
\hline Em nível & $\begin{array}{c}\text { Armazena água no solo e não } \\
\text { necessita de locais para o } \\
\text { escoamento do excesso de água }\end{array}$ & $\begin{array}{c}\text { Maior risco de rompimento e } \\
\text { exige limpezas mais frequentes }\end{array}$ \\
\hline Em desnível & Menor risco de rompimento & $\begin{array}{c}\text { Desvia água caída sobre a } \\
\text { gleba, necessita de locais } \\
\text { apropriados para escoar água e } \\
\text { possui maior dificuldade de } \\
\text { localização }\end{array}$ \\
\hline
\end{tabular}

Fonte: Adaptado de Bertol e Cogo (1996). 


\section{Considerações Finais}

A transição agroecológica é um processo complexo e longo, que visa a mudança sustentável dos sistemas de manejo do solo. Por esse motivo, durante a conversão da área, é recomendado que o produtor busque informações e troque experiências com técnicos especializados e outros agricultores que já fazem uso de práticas conservacionistas de manejo do solo.

A conversão de sistemas varia, principalmente, com o perfil do produtor, os recursos tecnológicos disponíveis e as características das espécies e da área de plantio. No início da transição, deve-se fazer o diagnóstico completo da área e por meio da análise do solo, observar a necessidade de calagem e adubação.

No início da transição, também é indicado fazer o controle da população de plantas espontâneas, pragas e doenças. Neste instante, ainda é possível utilizar agrotóxicos, pois à medida que o sistema é convertido, deve-se limitar gradativamente o uso e aplicação desses defensivos ao longo tempo, já que com o passar dos anos é esperado que o sistema entre em equilíbrio com o meio, sendo cada vez menos dependente de insumos químicos.

Apesar de ser desafiador, o trabalho durante o período de transição agroecológica é recompensado pelos inúmeros benefícios que este novo sistema traz ao produtor, sendo as principais vantagens observadas na melhoria da qualidade do solo e da água, no aumento da produtividade agrícola e na melhoria de qualidade de vida do produtor e sua família.

Dessa forma, as práticas de manejo do solo adotadas em áreas de transição agroecológica, como a adubação verde, o sistema plantio direto e o terraceamento, são fundamentais para melhorar os atributos físicos, químicos e biológicos do solo ao longo dos anos. O início da conversão é um período importante para aperfeiçoar, adaptar ou implementar outras práticas conservacionistas de manejo do solo. 
BOLETIM TÉCNICO - № 3

\section{Agradecimentos}

À Coordenação de Aperfeiçoamento de Pessoal de Nível Superior - CAPES pela bolsa de Pós-Graduação em Produção Vegetal concedida a Universidade Federal do Espírito Santo.

À Fundação de Amparo à Pesquisa e Inovação do Espírito Santo - FAPES pela bolsa de Pós-Graduação em Agroecologia concedida ao Instituto Federal do Espírito Santo - Campus de Alegre. 
BOLETIM TÉCNICO - № 3

ADAMS, G. A. Influência de diferentes tipos de plantas sobre a estrutura do solo em plantio direto. 2016. 45 p. Monografia (Curso de Graduação em Agronomia) - Universidade Federal da Fronteira Sul, Cerro Largo.

ALVARENGA, R. C; CABEZAS, W. A. L.; CRUZ, J. C.; SANTANA, D. P. Plantas de cobertura do solo para sistema plantio direto. Informe Agropecuário, Belo Horizonte, v. 22, n. 208, p. 25-36, 2001.

ARATANI, R. G.; FREDDI, O. S.; CENTURION, J. F.; ANDRIOLI, I. Qualidade física de um Latossolo vermelho acriférrico sob diferentes sistemas de uso e manejo. Revista Brasileira de Ciência dos Solos, Viçosa, v. 33, 2009.

BERTOL, I.; COGO, N. P. Terraceamento em sistemas de preparo conservacionistas de solo: um novo conceito. Lages: Sociedade Brasileira de Ciência do Solo, 1996. 41 p. (Boletim Técnico, 1)

BERTONI. J.; LOMBARDI, NETO, F. Conservação do solo. São Paulo: Editora Ícone, 1990.

CALEGARI, A. Plantas de cobertura. In: CASÃO JR., R.; SIQUEIRA, R. MEHTA, Y.R.; PASSINI, J.J. (Eds.). Sistema plantio direto com qualidade. Londrina: IAPAR, Foz do Iguaçu: ITAIPU Binacional, p. 55-73, 2006.

CAPORAL, F. R.; COSTABEBER, J. A. Agroecologia: alguns conceitos e princípios. Brasília: MDA/SAF/DATER-IICA, 2004. 24 p.

CORREA, L. A.; CRUZ, J. C. Plantio direto. Informe Agropecuário, Belo Horizonte, v. 13, n. 147 , p. $46-51,1987$.

DENARDIN, J. E.; KOCHHANN, R. A.; FAGANELLO, A.; SANTI, A.; DENARDIN, N. A. Diretrizes do sistema plantio direto no contexto da agricultura conservacionista. Passo Fundo: Embrapa Trigo, 2012. 15 p. (Documentos Online, 141)

DORAN, J. W.; PARKIN, T. B. Defining and assessing soil quality. In: DORAN, J. W.; COLEMAN, D. C.; BEZDICEK, D. F.; STEWART, B. A. (Eds.). Defining soil quality for a sustainable environment. Madison: Soil Science Society of America, p. 3-21, 1994. (SSSA special publication, 35)

ESPÍNDOLA, J. A. A.; GUERRA, J. G. M.; DE-POLLI, H.; ALMEIDA, D. L.; ABBOUD, A. C. S. Adubação verde com leguminosas. Brasília: Embrapa Informação Tecnológica, 2005. 49 p. (Coleção Saber)

ESPÍNDOLA, J. A. A.; GUERRA, J. G. M.; ALMEIDA, D. Adubação verde: estratégia para uma agricultura sustentável. Seropédica: Embrapa Agrobiologia, 1997. 20 p. (Documentos, 42).

FEIDEN, A.; ALMEIDA, D. L.; VITOI, V.; ASSIS, R. L. Processo de conversão de sistemas de produção convencionais para sistemas de produção orgânicos. Cadernos de Ciência \& Tecnologia, Brasília, v. 19, n. 2, p. 179-204, 2002.

FIORIN, J. E. Rotação de culturas e as plantas de cobertura de solo. In: FIORIN, J. E. (Coord.). Manejo e fertilidade do solo no sistema plantio direto. Passo Fundo: Berthier, p. 145-184, 2007. 
GONÇALVES, S. L.; GAUDÊNCIO, C. A.; FRANCHINI, J. C.; GALERANI, P. R.; GARCIA, A. Rotação de culturas. Londrina: Embrapa, 2007, 10 p. (Circular Técnica 45).

KARLEN, D. L.; MAUSBACH, M. J.; DORAN, J. W.; CLINE, R. G.; HARRIS, R. F.; SCHUMAN, G. E. Soil quality: A concept, definition, and framework for evaluation (a guest editorial). Soil Science Society of America Journal, v. 61, p. 4-10, 1997.

LIU, J.; HUE, N. V. Ameliorating subsoil acidity by surface application of calcium fulvates derived from common organic materials. Biology and Fertility of Soils, Berlim, v. 21, p. 264270, 1996.

LOMBARDI NETO, F; BELLINAZZI JUNIOR, R.; LEPSCH, I. F.; OLIVEIRA, J. B. de; BERTOLINI, D.; GALETI, P. A.; DRUGOWICH, M. Terraceamento agrícola. Campinas: Secretaria da Agricultura e do Abastecimento do Estado de São Paulo, Coordenadoria de Assistência Técnica Integral, 1994. 39 p. (Boletim Técnico, 206)

MACHADO, P. L. O. A.; WADT, P. G. S. Boas práticas agrícolas: terraceamento. Rio Branco: Embrapa Acre, 2016. 9 p.

MOREIRA, V. R. R. Adubação verde. Ministério da agricultura, Brasil, 2017a. Disponível em: $<$ http://www.agroecologia.gov.br/publicacoes/aduba\%C3\%A7\%C3\%A3o-verde >. Acesso em: 20 jul. 2020. (Fichas Agroecológicas)

MOREIRA, V. R. R. Adubação verde como fonte de nitrogênio. Ministério da agricultura, Brasil, 2017b. Disponível em: <http://www.agroecologia.gov.br/publicacoes/aduba\%C3\%A7\%C3\%A3o-verde-como-fontede-nitrog\%C3\%AAnio>. Acesso em: 20 jul. 2020. (Fichas Agroecológicas)

MOREIRA, V. R. R. Rotação de culturas em hortaliças. Ministério da agricultura, Brasil, 2013. Disponível em: <http://www.agroecologia.gov.br/sites/default/files/publicacoes/5rotacao-de-culturas.pdf>. Acesso em: 20 jul. 2020. (Fichas Agroecológicas)

OLIVEIRA, G. C.; PEREIRA, J. C.; MESQUITA, M. da G. B. F. Espaçamento entre terraços em função dos fatores que afetam as perdas por erosão. Informe Agropecuário, Belo Horizonte, 1992. v.16 n.176. p.51-56.

PRUSKY, F. F. Conservação de solo e água: práticas mecânicas para o controle da erosão hídrica. Viçosa: Editora UFV. 2009. 279 p.

SAGRILO, E.; LEITE, L. F. C.; GALVÃO, S. R. S.; LIMA, E. F. Manejo agroecológico do solo: os benefícios da adubação verde. Teresina: Embrapa Meio-Norte, 2009. 24 p. (Documentos)

SALOMÃO, P. E. A.; KRIEBEL, W.; SANTOS, A. A. dos; MARTINS, A. C. E. A importância do sistema de plantio direto na palha para reestruturação do solo e restauração da matéria orgânica. Research, Society and Development, v. 9, n. 1 p.1-21, 2020.

SILVA, T. O.; MENEZES, R. S. C. Adubação orgânica da batata com esterco e, ou, Crotalaria juncea. II - disponibilidade de N, P e K no solo ao longo do ciclo de cultivo. Revista Brasileira de Ciência do Solo, v. 31, n. 1, p. 51-61, 2007.

WADT, P. G. S. Construção de terraços para controle da erosão pluvial no estado do Acre. Rio Branco: Embrapa Acre, 2003. 44 p. (Documentos, 85) 
BOLETIM TÉCNICO - № 3

WUTKE, E. B.; AMBROSANO, E. J.; RAZERA, L. F.; MEDINA, P. F.; CARVALHO, L. H.; $\mathrm{KIKUTI}, \mathrm{H}$. Bancos comunitários de sementes de adubos verdes: informações técnicas. Brasília: Ministério da Agricultura, Pecuária e Abastecimento, 2007. 52 p. 